\title{
PENGARUH IKLAN DI TELEVISI, KUALITAS PRODUK DAN HARGA TERHADAP CITRA MEREK SERTA IMPLIKASINYA PADA MINAT PEMBELIAN (Survei Pada Calon Konsumen Susu SGM Di Kota Malang)
}

\author{
Evi Suwarni, Suharyono, Srikandi Kumadji \\ Fakultas Ilmu Administrasi, Universitas Brawijaya Malang \\ Email: evi_fia@ub.ac.id
}

\begin{abstract}
This study aims to analyze and explain the Influence of Advertising on Television, Product Quality and Price toward Brand Image and Its Implication on Purchase Intention. This research was conducted using a survey method of potential consumers of milk SGM in Malang, with a total sample of 102 respondents. The analytical tool used is Path Analysis. The results showed that (1) Advertising on Television have significant effect toward brand image, (2) Product Quality have significant effect toward Brand Image, (3) Price have significant effect toward brand image, (4) Advertising on Television significant effect toward Purchase Intention, (5) Product Quality have significant effect toward Purchase Intention, (6) Price do not have significant effect toward Purchase Intention, (7) Brand Image have significant effect toward Purchase Intention. The three findings of this study as follows: (1) Advertising on Television have significant influence both directly and indirectly to the Purchase Intention through brand image, (2) Product Quality have significant influence both directly and indirectly toward Purchase Intention through Brand Image, (3) Price directly effect does not have significant toward Purchase Intention, but indirectly Price through of Brand Image have significantly influence toward Purchasing Intention
\end{abstract}

Keywords: Advertising on television, Product Quality, Price, Brand Image and Purchase Intention

\begin{abstract}
ABSTRAK
Penelitian ini bertujuan untuk menganalisis dan menjelaskan pengaruh Iklan di Televisi, Kualitas Produk dan Harga terhadap Citra Merek serta Implikasinya pada Minat Pembelian. Penelitian ini dilakukan dengan menggunakan metode survei pada calon konsumen susu SGM di Kota Malang dengan jumlah sampel sebanyak 102 orang responden. Alat analisis yang digunakan adalah analisis jalur (Path Analysis). Hasil penelitian menunjukkan bahwa (1) Iklan di Televisi berpengaruh signifikan terhadap Citra Merek, (2) Kualitas Produk berpengaruh signifikan terhadap Citra Merek, (3) Harga berpengaruh signifikan terhadap Citra Merek, (4) Iklan di Televisi berpengaruh signifikan terhadap Minat Pembelian, (5) Kualitas Produk berpengaruh signifikan terhadap Minat Pembelian, (6) Harga berpengaruh tidak signifikan terhadap Minat pembelian, (7) Citra Merek berpengaruh signifikan terhadap Minat Pembelian.
\end{abstract}

Keywords: Advertising on television, Product Quality, Price, Brand Image and Purchase Intention 


\section{PENDAHULUAN}

Indonesia telah memasuki pasar bebas Asean Economic Community atau Masyarakat Ekonomi ASEAN (MEA) tanggal 31 Desember 2015 yang lalu, menjadikan Indonesia sebagai pangsa pasar yang sangat potensial. Indonesia sudah pasti akan menjadi bidikan negara-negara ASEAN. Hal ini dipicu dengan pertumbuhan penduduk cukup tinggi dengan rasio ketergantungan yang mengecil. Selain itu, pertumbuhan ekonomi yang cukup tinggi dengan pendapatan per kapita yang terus meningkat. Indonesia memiliki luas wilayah dan jumlah penduduk yang terbesar di kawasan (40\% dari total pendudukASEAN)(pphp.pertanian.go.id, 2015). Data dari BKKBN pada sensus tahun 2010, persentase balita pada usia 0-4 tahun sebanyak 22.678.702 orang atau sebanyak $9.5 \%$ dari total penduduk Indonesia sebanyak 237.641.326 orang. Masih tingginya angka kelahiran bayi di Tanah Air membuat Indonesia menjadi salah satu pasar utama dalam pemasaran produk susu formula. Asia Pasifik merupakan pasar utama industri susu formula, khususnya Indonesia dan China selain jumlah penduduk yang sangat besar, tidak adanya regulasi pemerintah yang mengatur pemasaran susu formula membuat pihak produsen dengan bebasnya mempromosikan produknya di Indonesia (Kompas, 2010).

Melihat fakta tersebut maka bisa dikatakan penjualan susu formula adalah merupakan bisnis perdagangan yang sangat besar dan menguntungkan. Oleh karena itu, pertumbuhan pasar susu formula di Indonesia sangatlah besar. Hampir sebagian besar pasar ini dikuasai oleh susu formula dengan harga yang terjangkau dan sisanya adalah susu dengan segmentasi harga premium dan superpremium. Ada tiga perusahaan besar yang menguasai pasar susu pertumbuhan dengan harga terjangkau yakni Sari Husada, Nestle, dan Frisian Flag. Setiap perusahaan menentukan strategi dalam memenangkan persaingan merebut pangsa pasar yang potensial di Indonesia, seperti halnya produsen susu SGM yang gencar mengiklankan produknya dalam televisi. Susu formula SGM selalu berhasil mendapatkan peringkat pertama dalam top brand survey susu pertumbuhan di Indonesia. Salah satu cara yang dilakukan perusahaan adalah mempelajari perilaku konsumen sehingga dapat menentukan strategi apa yang sebaiknya dilakukan agar konsumen tertarik terhadap suatu produk. Selain itu, Kunci untuk merebut pangsa pasar dalam industri susu pertumbuhan adalah dengan mempertimbangankan harga yang terjangkau, kualitas produk yang baik serta dengan adanya iklan di televisi yang bersifat informatif dan persuasif sehingga hal ini membentuk citra merek yang positif. Persepsi konsumen terhadap harga, kualitas produk dan iklan yang kemudian membentuk citra merek dari SGM akan berpengaruh secara signifikan terhadap minat pembelian dari calon konsumen.

Minat pembelian adalah kemungkinan bahwa pelanggan akan membeli produk tertentu (Fishbein and Ajzen, 1975; Dodds et al., 1991; Schiffman and Kanuk, 2000). Jika keinginan yang lebih besar untuk membeli suatu produk maka kemungkinan untuk membelinya akan lebih tinggi, tetapi belum tentu untuk benarbenar membelinya. Sebaliknya, bila keinginan yang lebih rendah untuk membeli suatu produk tidak berarti mustahil untuk membelinya. Bagozzi and Burnkrant (1979) mendefinisikan minat beli sebagai kecenderungan perilaku pribadi terhadap produk tertentu. Minat pembelian dipengaruhi oleh berbagai faktor, antara lain: Iklan (Lin, 2011; Gilaninia and Mousavian, 2012), Kualitas Produk (Shehzad, 2011; Yang et al., 2013), Harga (Lien et al., 2014; Semuela dan Chandraa, 2014) dan Citra Merek (Wang and Tsai, 2014; Lien et al., 2014). Berdasarkan latar belakang maka penelitian ingin mengkaji tentang Iklan di Televisi, Kualitas Produk dan Harga serta pengaruhnya terhadap Citra Merek yang nantinya akan berdampak pada minat pembelian calon konsumen .

\section{LATAR BELAKANG TEORI DAN HIPOTESIS Hubungan antara Iklan di Televisi dan Citra Merek}

Iklan sebagai pengingat sangat penting bagi produk karena periklanan membantu memelihara hubungan pelanggan dengan membuat konsumen terus memikirkan produk (Kotler dan Armstrong, 2008, h. 152). Iklan adalah komunikasi tidak langsung, yang didasari pada informasi tentang keunggulan 
atau keuntungan suatu produk, yang disusun sedemikian rupa sehingga menimbulkan rasa menyenangkan yang akan mengubah pikiran seseorang untuk melakukan pembelian (Tjiptono, 1997, h. 22). Hasil penelitian Gilaninia and Mousavian (2012) menunjukkan bahwa, dengan menggunakan iklan, kepuasan pelanggan dan inovasi berkorelasi positif dengan citra merek.

\section{Hubungan antara Iklan di Televisi dan Minat Pembelian}

Iklan telah menjadi salah satu kegiatan komersial yang paling penting dalam lingkungan yang kompetitif modern. Perusahaan menghabiskan sebagian besar anggaran mereka untuk menghasilkan dan menjalankan iklan untuk promosi untuk berkomunikasi informasi tentang perusahaan dan produk mereka. Perusahaan berharap bahwa konsumen akan membeli produk mereka karena iklan yang menyampaikan pesan tentang merek tertentu dan produk-produknya. Thorson dan Leavitt (1992) menyatakan bahwa pembawa pesan terbaik untuk pembelian adalah iklan. Hasil Penelitian dari Lin (2011) iklan memiliki pengaruh signifikan positif terhadap minat pembelian.

\section{Hubungan antara Kualitas Produk dan Citra Merek}

Kualitas produk adalah karakteristik produk atau jasa yang bergantung pada kemampuannya untuk memuaskan kebutuhan pelanggan yang dinyatakan atau diimplikasikan (Kotler dan Armstrong, 2008, h. 272). Kualitas produk memiliki dua dimensi utama, yaitu tingkatan dan konsistensi. Dalam mengembangkan produk, pemasar harus terlebih dahulu memilih tingkatan kualitas yang dapat mendukung posisi produk di pasar sasaran. perilaku pembelian konsumen, persepsi kualitas produk dan harga mempunyai hubungan yang kuat dan positif terhadap citra merek atau nama merek Shehzad et al. (2011). Hasil penelitian Yusmawan (2014) Kualitas produk berpengaruh positif dan signifikan terhadap citra merek .

\section{Hubungan antara Kualitas Produk dan Minat Pembelian.}

Persepsi kualitas Produk adalah penilaian konsumen tentang keseluruhan keunggulan produk dan keunggulan, bukan kualitas sebenarnya dari produk (Zeithaml, 1988; Aaker,
1991). Konsumen sering menilai kualitas produk melalui isyarat informasi. Mereka membentuk keyakinan atas dasar ini isyarat informasi (intrinsik dan ekstrinsik), dan kemudian menilai kualitas produk dan membuat keputusan pembelian akhir mereka berdasarkan keyakinan ini (Olson, 1977). Menurut Zeithaml (1988), atribut intrinsik adalah karakteristik fisik dari produk itu sendiri, seperti produk kesesuaian, daya tahan, fitur, kinerja, kehandalan, dan servis. Sebaliknya, atribut ekstrinsik adalah isyarat eksternal untuk produk itu sendiri, seperti harga, citra merek, dan reputasi perusahaan. Hasil Penelitian yang dilakukan oleh Yang et al. (2009) menyatakan bahwa Kualitas produk berpengaruh positif signifikan terhadap minat pembelian.

Hubungan antara Harga dan Citra Merek

Menurut Swasta dan Sukotjo (2002), harga adalah sejumlah uang yang dibutuhkan untuk mendapatkan sejumlah kombinasi dari barang atau jasa beserta pelayanannya. Sedangkan menurut Kotler (2005, h. 139), harga merupakan salah satu elemen bauran pemasaran paling fleksibel, harga dapat berubah dengan cepat tidak seperti produk dan perjanjian distribusi. Dari sudut pandang konsumen, harga merupakan jumlah uang konsumen harus menyerah untuk mendapatkan produk / jasa (Zeithaml, 1988).

Banyak konsumen menggunakan harga sebagai kualitas-sinyal isyarat mencerminkan pepatah konvensional bahwa "Anda mendapatkan apa yang Anda bayarkan "(Erickson \& Johansson, 1985). Konsumen tidak selalu ingat harga aktual produk. Sebaliknya, mereka mengkodekan harga di cara yang bermakna bagi mereka (Zeithaml, 1988). Hasil Penelitian yang dilakukan oleh Shehzad et al. (2011) Harga mempunyai hubungan yang kuat dan positif terhadap citra merek atau nama merek.

\section{Hubungan antara Harga dan Minat Pembelian.}

Harga Kotler (2011) didefinisikan sebagai jumlah uang yang dibebankan (atau dalam pertukaran) untuk produk atau jasa. Keller (2008) menyatakan bahwa konsumen sering aktif Informasi harga proses berdasarkan pengetahuan dan Pengalaman pengalaman pembelian sebelumnya. Meskipun konsumen mungkin tidak dapat persis mengingat produk 
harga, mereka umumnya tahu kisaran harga untuk kategori produk tertentu. Ada beberapa strategi yang menggunakan harga untuk mempengaruhi keputusan pembelian konsumen. Penelitian dilakukan oleh Sarwar et al. (2013) yang bertujuan untuk mengetahui pengaruh harga dan persepsi konsumen dalam membeli produk buatan Cina. Disimpulkan bahwa ada hubungan positif yang ada antara harga dan persepsi konsumen terhadap membeli Cina produk. Hasil penelitian yang dilakukan Lien et al.(2015) harga berpengaruh signifikan terhadap minat pembelian.

\section{Hubungan antara Citra Merek dan Minat Pembelian}

Citra merek menurut Kotler dan Keller (2009, h. 346) adalah persepsi dan keyakinan yang dilakukan oleh konsumen, seperti tercermin dalam asosiasi yang terjadi dalam memori konsumen. Citra Merek merupakan isyarat penting selama proses pengambilan keputusan pembelian konsumen. Baik Informasi merek positif mempengaruhi persepsi kualitas, nilai yang dirasakan, dan kemauan konsumen untuk membeli (Dodds, Monroe \& Grewal, 1991; Monroe dan Krishnan, 1985). Konsumen lebih cenderung membeli produk merek terkenal dengan Citra Merek yang positif, karena merek dengan citra yang lebih positif memang memiliki efek menurunkan risiko yang dirasakan konsumen. Hasil Penelitian (Wu et al., 2011), citra merek mempengaruhi minat pembelian). Harga dan citra merek berpengaruh signifikan terhadap minat pembelian Lien et al.(2015).

\section{Model dan Hipotesis Penelitian}

Adapun secara konseptual keterkaitan antar variabel tersebut dapat dilihat pada Gambar

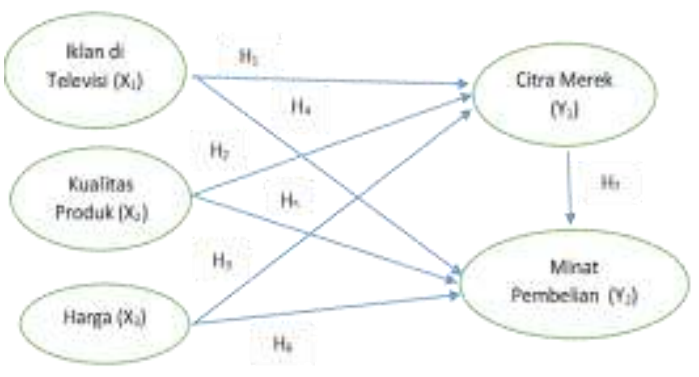

Gambar 1 Model Hipotesis Penelitian

Sumber : Data diolah (2015)

\section{Hipotesis Penelitian}

Berdasarkan model penelitian tersebut, maka hipotesis dalam penelitian ini dapat diuraikan sebagai berikut:

$\mathrm{H}_{1}$ : Iklan di Televisi berpengaruh signifikan terhadap

Citra Merek

$\mathrm{H}_{2}$ : Kualitas produk berpengaruh signifikan terhadap

Citra Merek

$\mathrm{H}_{3}$ : Harga berpengaruh signifikan terhadap Citra Merek

$\mathrm{H}_{4}$ : Iklan di Televisi berpengaruh signifikan terhadap

Minat Pembelian

$\mathrm{H}_{5}$ : Kualitas produk berpengaruh signifikan terhadap

Minat Pembelian

$\mathrm{H}_{6}$ : Harga berpengaruh signifikan terhadap Minat

Pembelian

$\mathrm{H}_{7}$ : Citra Merek berpengaruh signifikan terhadap Minat

Pembelian

\section{METODE PENELITIAN}

Jenis penelitian ini termasuk dalam jenis penelitian eksplanatori dengan pendekatan kuantitatif. Penelitian ini menggunakan metode survei dengan angket sebagai pengumpul data primer. Lokasi penelitian ini adalah di Kota Malang. Populasi sampel di dalam penelitian ini yaitu penduduk di kota Malang yaitu orang tua yang mempunyai anak usia 1-3 tahun dengan kriteria :

1. Belum menggunakan produk susu SGM.

2. Pernah melihat iklan susu SGM di televisi.

Penentuan jumlah sampel juga dapat dilihat dalam Tabel Machin (Machin and Champbell, 1987, p. 89). Penentuan jumlah sampel dalam penelitian ini mengambil $r=0,347 ; \alpha=0,10$; dan $\beta=0,05$ maka diperoleh jumlah sampel sebanyak 102 orang responden.. Teknik Pengambilan sampel dilakukan dengan menggunakan teknik Sampel Bertingkat (Stratifikasi) atau biasa juga disebut sampel gugus bertahap. Berdasarkan hipotesis dan rancangan penelitian, maka data yang terkumpul dalam penelitian ini akan dianalisis 
dengan menggunakan teknik analisis jalur (path analysis).

\section{HASIL PENELITIAN DAN PEMBAHASAN}

\subsection{Hasil Penelitian Analisis Inferensial}

Tabel 1 Hasil Koefisien Path Substruktur 1 ( $\mathrm{X}_{1}, \mathrm{X}_{2}, \mathrm{X}_{3}$ terhadap $\mathrm{Y}_{1}$ )

\begin{tabular}{|c|c|c|c|c|}
\hline $\begin{array}{c}\text { Variabel } \\
\text { Independen }\end{array}$ & $\begin{array}{c}\text { Standardized } \\
\text { Coefficients } \\
\text { (Beta) }\end{array}$ & t-hitung & Sig & Keterangan \\
\hline$X_{1}$ & 0.15 & 2,040 & 0.044 & Signifikan b \\
$X_{2}$ & 0.438 & 5,372 & 0,000 & Signifikan \\
$X_{3}$ & 0.392 & 5,787 & 0,000 & Signifikan p \\
\hline
\end{tabular}

Variabel Independe: $Y$,

R Square

0.786

Hasil analisis jalur untuk substruktur 1 pada Tabel tersebut digunakan untuk mengetahui pengaruh Iklan di Televisi $\left(\mathrm{X}_{1}\right)$, Kualitas Produk $\left(\mathrm{X}_{2}\right)$ dan Harga $\left(\mathrm{X}_{3}\right)$ terhadap Citra Merek $\left(\mathrm{Y}_{1}\right)$ secara simultan dan parsial. Besarnya R Square pada hubungan ini sebesar 0.786 atau 78,6\%. Angka tersebut menunjukkan pengaruh Iklan di Televisi, Kualitas Produk dan Harga terhadap Citra Merek secara simultan sebesar $78,6 \%$ sedangkan sisanya $22,4 \%$ dipengaruhi oleh faktor yang lain. Untuk melihat besarnya pengaruh variabel Iklan di Televisi $\left(\mathrm{X}_{1}\right)$, Kualitas Produk $\left(\mathrm{X}_{2}\right)$ dan Harga $\left(\mathrm{X}_{3}\right)$ terhadap Citra Merek $\left(\mathrm{Y}_{1}\right)$ secara parsial maka digunakan Uji-t dengan menggunakan Standardized Coefficient.

a. Pengaruh Iklan di Televisi $\left(\mathrm{X}_{1}\right)$ terhadap Citra Merek $\left(\mathrm{Y}_{1}\right)$

Hasil perhitungan koefisien jalur antara Iklan di Televisi terhadap Citra Merek menunjukkan bahwa nilai Standardized Coefficient $=0,150$ atau $15 \%$ dengan t-hitung sebesar 2,040 > t-Tabel 1,984 sehingga $\mathrm{H}_{0}$ ditolak. Sedangkan besarnya pengaruh parsial Iklan di Televisi terhadap Citra Merek nilai Sig $0,044 \quad(<0,05)$ sehingga pengaruh tersebut dianggap signifikan.

b. Pengaruh Kualitas Produk $\left(\mathrm{X}_{2}\right)$ terhadap Citra Merek $\left(\mathrm{Y}_{1}\right)$

Hasil perhitungan koefisien jalur antara Kualitas Produk terhadap Citra Merek menunjukkan bahwa nilai Standardized Coefficient $=0,438$ atau $43,8 \%$ dengan t-hitung sebesar 5,372 > t-Tabel 1,984 sehingga $\mathrm{H}_{0}$ ditolak. Sedangkan besarnya pengaruh parsial Kualitas Produk terhadap Citra Merek nilai Sig $0,000 \quad(<0,05)$ sehingga pengaruh tersebut dianggap signifikan.

c. Pengaruh Harga $\left(\mathrm{X}_{3}\right)$ terhadap Citra Merek $\left(\mathrm{Y}_{1}\right)$

Hasil perhitungan koefisien jalur antara Harga terhadap Citra Merek menunjukkan bahwa nilai Standardized Coefficient $=0,392$ atau 39,2\% dengan t-hitung sebesar 5,787 > tTabel 1,984 sehingga $\mathrm{H}_{0}$ ditolak. Sedangkan esarnya pengaruh parsial Harga terhadap Citra Merek Nilai Sig 0,000 (< 0,05$)$ sehingga pengaruh tersebut dianggap signifikan.

Tabel 2 Hasil Koefisien Path Substruktur 2 ( $X_{1}, X_{2}, X_{3}, Y_{1}$ terhadap $\left.Y_{2}\right)$

\begin{tabular}{|c|c|c|c|c|}
\hline $\begin{array}{c}\text { Variabel } \\
\text { Independen }\end{array}$ & $\begin{array}{c}\text { Standardized } \\
\text { Coefficients } \\
\text { (Beta) }\end{array}$ & t-hitung & Sig & Keterangan \\
\hline$X_{1}$ & 0.229 & 2.312 & 0.023 & Signifikan \\
$X_{2}$ & 0.257 & 2.098 & 0.039 & Signifikan \\
$X_{3}$ & 0.075 & 0.727 & 0.469 & Tidak Signifikan \\
$Y_{1}$ & 0.309 & 2.313 & 0.023 & Signifikan \\
\hline Variabel Depender: $Y_{2}$ \\
$R$ Square \\
\hline
\end{tabular}

Besarnya $R$ Square pada hubungan ini sebesar 0.630 atau 63\%. Angka tersebut menunjukkan pengaruh Iklan di Televisi, Kualitas Produk, Harga dan Citra Merek terhadap Minat Pembelian secara simultan sebesar $63 \%$ sedangkan sisanya $37 \%$ dipengaruhi oleh faktor yang lain. Kemudian untuk mengetahui kelayakan model regresi menggunakan perbandingan taraf signifikansi (Probabilitas F-hitung) penelitian dengan taraf signifikansi penelitian sebesar $0,000 \leq 0,05$ maka $\mathrm{H}_{0}$ ditolak dan $\mathrm{H}_{1}$ diterima. Untuk melihat besarnya pengaruh variabel Iklan di Televisi $\left(\mathrm{X}_{1}\right)$, Kualitas Produk $\left(\mathrm{X}_{2}\right)$, Harga $\left(\mathrm{X}_{3}\right)$ dan Citra Merek $\left(\mathrm{Y}_{1}\right)$ terhadap Minat Pembelian $\left(\mathrm{Y}_{2}\right)$ secara parsial maka digunakan Uji-t dengan menggunakan Standardized Coefficient.

a. Pengaruh Iklan di Televisi $\left(\mathrm{X}_{1}\right)$ terhadap Minat Pembelian ( $\left.\mathrm{Y}_{2}\right)$

Hasil perhitungan koefisien jalur antara Iklan di Televisi terhadap Minat Pembelian menunjukkan bahwa nilai Standardized Coefficient $=0,229$ atau 22,9\% dengan t-hitung sebesar 2,312 > t-Tabel 1,984 sehingga $\mathrm{H}_{0}$ ditolak. Sedangkan besarnya pengaruh parsial Iklan di Televisi terhadap Minat Pembelian 
dengan nilai Sig 0,0023 (< 0,05) sehingga pengaruh tersebut dianggap signifikan.

b. Pengaruh Kualitas Produk $\left(\mathrm{X}_{2}\right)$ terhadap Minat Pembelian $\left(\mathrm{Y}_{2}\right)$

Hasil perhitungan koefisien jalur antara Kualitas Produk terhadap Minat Pembelian menunjukkan bahwa nilai Standardized Coefficient $=0,257$ atau $25,7 \%$ dengan t-hitung sebesar $2.098>$ t-Tabel 1,984 sehingga $\mathrm{H}_{0}$ ditolak. Sedangkan besarnya pengaruh parsial Kualitas Produk terhadap Minat Pembelian dengan nilai Sig $0,039(<0,05)$ sehingga pengaruh tersebut dianggap signifikan.

c. Pengaruh Harga $\left(\mathrm{X}_{3}\right)$ terhadap Minat Pembelian $\left(\mathrm{Y}_{2}\right)$

Hasil perhitungan koefisien jalur antara Harga terhadap Minat Pembelian menunjukkan bahwa nilai Standardized Coefficient $=0,075$ atau 7,5\% dengan t-hitung sebesar $0,727<\mathrm{t}$ Tabel 1,984 sehingga $\mathrm{H}_{0}$ diterima. Sedangkan besarnya pengaruh parsial Harga terhadap Minat Pembelian dengan nilai Sig 0,469 (< $0,05)$ sehingga pengaruh tersebut dianggap tidak signifikan.

d. Pengaruh Citra Merek $\left(\mathrm{Y}_{1}\right)$ terhadap Minat Pembelian $\left(\mathrm{Y}_{2}\right)$

Hasil perhitungan koefisien jalur antara Citra Merek terhadap Minat Pembelian menunjukkan bahwa nilai Standardized Coefficient $=0.309$ atau 30,9\% dengan t-hitung sebesar 2,313 > t-Tabel 1,984 sehingga $\mathrm{H}_{0}$ ditolak. Sedangkan besarnya pengaruh parsial Iklan di Televisi terhadap Citra Merek Nilai Sig $0,023 \quad(<0,05)$ sehingga pengaruh tersebut dianggap signifikan.

Keterangan Gambar

$\longrightarrow$ : Pengaruh Positif dan Signilikan

$\ldots$ - Pengaruh Positif dan Tidak Signifinan

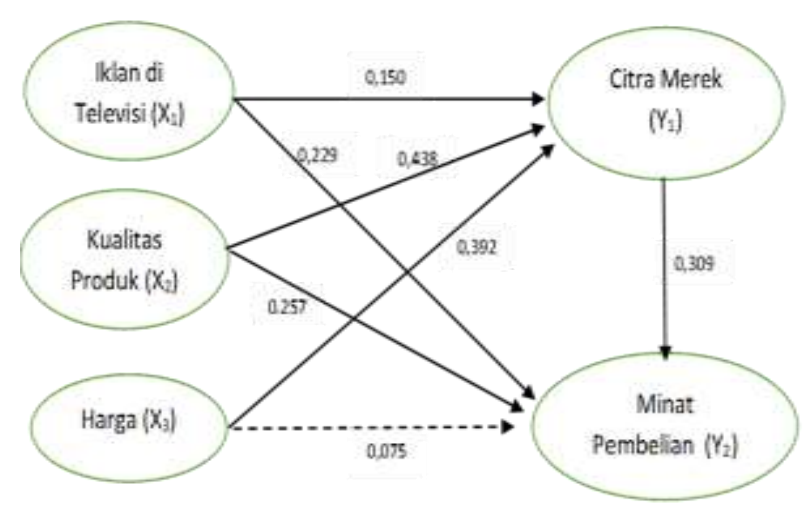

Gambar 2 Model Persamaan Jalur

\subsection{Pembahasan}

Berdasarkan hasil analisis penelitian baik secara deskriptif maupun inferensial yang telah dilakukan oleh pengujian teori - teori dalam model penelitian ini, maka akan ditarik kesimpulan sebagai berikut :

1. Iklan di Televisi berpengaruh signifikan terhadap Citra Merek

Hasil Penelitian dapat disimpulkan bahwa hipotesis pertama yang menyatakan Iklan di Televisi terhadap Citra Merek berpengaruh signifikan dapat diterima. Pengaruh antar variabel tersebut positif artinya semakin baik persepsi calon konsumen terhadap Iklan di Televisi maka akan meningkat Citra Merek susu SGM. Hal ini dapat diketahui melalui tingginya nilai indikator calon konsumen mengetahui produk dan manfaat produk melalui Iklan di Televisi.

2. Kualitas Produk berpengaruh signifikan terhadap Citra Merek

Hasil Penelitian dapat disimpulkan bahwa hipotesis kedua yang menyatakan Kualitas Produk terhadap Citra Merek berpengaruh signifikan dapat diterima. Pengaruh antar variabel tersebut positif artinya semakin baik persepsi calon konsumen tentang kualitas produk susu SGM maka akan semakin meningkatkan persepsi terhadap Citra Merek. Hal ini dapat diketahui melalui tingginya nilai indikator keamanan kualitas produk yang tecantum label halal dan terdaftar di BPOM.

3. Harga berpengaruh signifikan terhadap Citra Merek

Hasil Penelitian dapat disimpulkan bahwa hipotesis ketiga yang menyatakan Harga terhadap Citra Merek berpengaruh signifikan dapat diterima. Pengaruh antar variabel tersebut positif artinya semakin baik persepsi calon konsumen tentang harga maka akan meningkatkan Citra Merek produk. Hal ini tampak dari tingginya nilai indikator Kewajaran dari Perusahaan dalam menetapkan harga, dan indikator kesesuaian harga dengan tingkat daya beli calon konsumen.

4. Iklan di Televisi berpengaruh signifikan terhadap Minat Pembelian

Hasil Penelitian dapat disimpulkan bahwa hipotesis keempat yang menyatakan Iklan di 
Televisi terhadap Minat Pembelian berpengaruh signifikan dapat diterima. Baik pengaruh secara langsung maupun tidak langsung yaitu melalui variabel Citra Merek, Iklan di Televisi mempunyai pengaruh yang signifikan dan positif terhadap Minat Pembelian.

5. Kualitas Produk berpengaruh signifikan terhadap Minat Pembelian

Hasil Penelitian dapat disimpulkan bahwa hipotesis kelima yang menyatakan Kualitas Produk terhadap Minat Pembelian berpengaruh signifikan dapat diterima. Baik pengaruh secara langsung maupun tidak langsung yaitu melalui variabel Citra Merek, Kualitas Produk mempunyai pengaruh yang signifikan dan positif terhadap Minat Pembelian.

6. Harga berpengaruh tidak signifikan terhadap Minat Pembelian

Hasil Penelitian dapat disimpulkan bahwa hipotesis enam yang menyatakan Harga terhadap Minat Pembelian berpengaruh signifikan tidak dapat diterima. Harga memang mempunyai pengaruh tidak signifikan secara langsung, tetapi secara tidak langsung yaitu melalui variabel Citra Merek, variabel Harga mempunyai pengaruh yang signifikan dan positif terhadap Minat Pembelian.

7. Citra Merek berpengaruh signifikan terhadap Minat Pembelian

Hasil Penelitian dapat disimpulkan bahwa hipotesis ketujuh yang menyatakan Citra Merek terhadap Minat Pembelian berpengaruh signifikan dapat diterima. Pengaruh antar variabel tersebut positif artinya Citra Merek yang positif dan baik tentang produk susu SGM maka akan membuat Minat Pembelian calon konsumen ikut meningkat. Hal ini dapat diketahui dari tingginya indikator nilai Citra Merek yaitu Iklan Merek dan Promosi susu SGM unik dan mudah di ingat, dari segi kesan tampilan fisik yang khas dan mudah dikenali oleh calon konsumen.

\section{Keterbatasan Penelitian}

Beberapa keterbatasan dalam penelitian yang ditemui adalah sebagai berikut: Penelitian ini dilakukan pada produk SGM Eksplore 1+ untuk anak usia 1 - 3 tahun, sehingga hasil penelitian ini tidak memungkinkan untuk di generalisir pada produk susu atau produk yang lain dan waktu penelitian yang berbeda.

\section{KESIMPULAN DAN SARAN}

\section{Kesimpulan}

a. Iklan di Televisi berpengaruh signifikan terhadap Citra Merek. Hasil Penelitian dapat disimpulkan bahwa semakin baik persepsi calon konsumen terhadap Iklan di Televisi maka akan meningkat Citra Merek susu SGM.

b. Kualitas Produk berpengaruh signifikan terhadap Citra Merek. Hasil Penelitian dapat disimpulkan bahwa semakin baik persepsi calon konsumen tentang kualitas produk susu SGM maka akan semakin meningkatkan persepsi terhadap Citra Merek.

c. Harga berpengaruh signifikan terhadap Citra Merek. Hasil Penelitian dapat disimpulkan bahwa semakin baik persepsi calon konsumen tentang harga maka akan meningkatkan Citra Merek produk.

d. Iklan di Televisi berpengaruh signifikan terhadap Minat Pembelian. Hasil Penelitian dapat disimpulkan bahwa semakin baik persepsi calon konsumen terhadap Iklan di Televisi maka akan meningkat Minat Pembelian susu SGM. Baik secara langsung maupun tidak langsung melalui Citra Merek

e. Kualitas Produk berpengaruh signifikan terhadap Minat Pembelian. Hasil Penelitian dapat disimpulkan bahwa semakin baik persepsi calon konsumen tentang kualitas produk susu SGM maka akan semakin meningkatkan persepsi terhadap Minat Pembelian baik secara langsung maupun tidak langsung melalui Citra Merek.

f. Harga berpengaruh tidak signifikan terhadap Minat Pembelian. Hasil Penelitian dapat disimpulkan bahwa Harga memang mempunyai pengaruh tidak signifikan secara langsung, tetapi secara tidak langsung yaitu melalui variabel Citra Merek, variabel Harga mempunyai pengaruh yang signifikan dan positif terhadap Minat Pembelian.

g. Citra Merek berpengaruh signifikan terhadap Minat Pembelian. Hasil Penelitian dapat disimpulkan bahwa semakin baik persepsi calon konsumen tentang Citra Merek susu SGM maka akan semakin 
meningkatkan persepsi terhadap Minat Pembelian.

\section{Saran}

1. Bagi peneliti selanjutnya mampu mengembangkan konseptual dan model kajian penelitian yang selanjutnya lebih luas dengan tetap pada konteks Iklan di Televisi, Kualitas Produk, Harga terhadap Citra Merek serta implikasinya terhadap Minat Pembelian.

2. Bagi Perusahaan PT. Sarihusada diharapkan mampu menyaring hal-hal apa saja yang sekiranya dapat disadur dari penelitian ini memperhatikan Iklan di Televisi, Kualitas Produk dan Harga dapat mempengaruhi Citra Merek produk SGM dan berpengaruh terhadap Minat Pembelian bagi calon konsumen. Dengan mempertahankan Citra Merek yang baik dan Top Brand selama 4 tahun berturutturut sehingga mampu menarik Minat Pembelian calon konsumen.

\section{DAFTAR PUSTAKA}

Aaker, D. A .1991. "Managing Brand Equity: Capitalizing on the Value of a Brand Name," New York. The Free Press.

Akaah, I. P. \& Korgaonkar, P. K. 1988 “A Conjoint Investigation of the Relative Importance of Risk Relievers in Direct Marketing," Journal of Advertising Research, vol.28(August/September), p. 38-44.

Bagozzi, R. P., \& Burnkrant, R. E .1979. "Attitude Organization and AttitudeBehavior Relationship ,"Journal of Personality and Social Psychology, vol. 37(1), pp. 913-929.

Dodds, W. B., Monroe, K. B. \& Grewal, D (1991) "Effects of Price, Brand, and Store Information on Buyers' Product Evaluation," Journal of Marketing Research, vol. 28, p. 307-319.

Erickson, G. M., \& Johansson, J. K. (1985). The role of price in multi-attribute product evaluations. Journal of Consumer Research, 12(2), 195e199.
Fishbein, M., \& Ajzen, I. 1975. Belief, Attitude, Intention and Behavior: an Introduction to Theory and Research," Reading, MA: Addison-Wesley. Washington

Gilaninia, Shahram., and Seyyed Javad Mousavian. 2012. "The investigation and analysis impact of brand image in Iran". African Journal of Business Management Vol.6 (25), pp. 7548-7556

Kotler, Philip. 2005. Manajamen Pemasaran, Jilid 1 dan 2. PT. Indeks Kelompok Gramedia. Jakarta.

2008. Prinsip-Prinsip Pemasaran. Terjemah oleh Bob Sabran. Edisi ke 12. Erlangga. Jakarta

Kotler, Philip, dan Gary Armstrong. 2003. Dasar-Dasar Pemasaran. Terjemah oleh Alex Sindoro. Edisi ke 9. jilid 1. PT. Indeks Kelompok Gramedia. Jakarta.

Kotler. Philip dan Kevin Lane Keller. 2009. Manajemen Pemasaran. Terjemah oleh Bob Sabran. Edisi ke 13, Jilid 1, Erlangga, Jakarta.

Lien, Che-Hui, Miin-Jye Wen, Li-Ching Huang, Kuo-Lung Wu. 2015. "Online hotel booking: The effects of brand image, price, trust and value on purchase intentions". Asia Pacific Management Review Vol xxx pp 1-9

Lin, Long Yi. 2011. "The Impact Of Advertising Appeals And Advertising Spokespersons On Advertising Attitudes And Purchase Intentions". African Journal of Business Management Vol. 5(21), pp. 8446-8457.

Machin, David \& Michael Campbell.1987. Statistical Table for the Design of Clinical Trial. Blackwell Scientific Publication. London.

McCarthy, E. Jerome., Cannon, Joseph P., William D. Perreault Jr. 2008. Pemasaran Dasar : Pendekatan Manajerial Global. Terjemah oleh Diana Angelica dan Ria Cahyani. Buku 2. Edisi 16. Salemba Empat. Jakarta. 
Monroe, K. B. \& Krishnan, R .1985. "The Effect of Price on Subjective Product Evaluation,"

Jacob and Jerry C. Olson (Eds.), Perceived Quality: How Consumers View Stores and Merchandise, MA.Lexington Books.

Olson, J. C (1977) "Price as an Information Cue: Effects in Product Evaluation," In
A.
$\mathrm{G}$.
Woodside,
$\mathrm{J}$.

N. Sheh, and P. D. Bennet (Eds.) Consumer and Industrial Buying Behavior, New York: North HollandPublishing Company, p. 267-286.

Sarwar, A., Azam, S.M. F., Haque, A., Sleman, G. \& Nikhashemi, S.R. 2013. Customer's perception towards buying Chinese products: An empirical investigation in Malaysia. World Applied Sciences Journal, 22 (2), 152-160.

Schiffman, L. G. \& Kanuk, L. L .2000. Consumer Behavior, 7th ed., PrenticeHall

Semuela, Hatane and Sharon Sagita Chandra. 2014."The Analysis of Corporate Social Responsibility Implementation Effects towards Price Fairness, Trust and Purchase Intention at Oriflame Cosmetics Product in Surabaya". Procedia - Social and Behavioral Sciences 155 pp.42 - 47

Shehzad, Umer., Salman Ahmad, Kashif Iqbal, Muhammad Nawaz, Saqib Usman. 2014. "Influence of Brand Name on Consumer Choice \& Decision". IOSR Journal of Business and Management (IOSR-JBM). Volume 16, Issue 6. Ver. III (Jun. 2014), PP 72-76.

Swastha, Basu, Ibnu Sukotjo. 2002. Pengantar Bisnis Modern. Cetakan ketiga, Liberty, Yogyakarta.

Thorson E, Leavitt C.1992. Attention, Memory, Attitude, and Conation:A test of the advertising hierarchy. Adv. Cons. Res., 19(1): 366-379.

Tjiptono, Fandy. 1997. Strategi Pemasaran. Edisi 1. Andi Offset. Yogyakarta.
Wang, Ya-Hui and Cing-Fen Tsai (2014) "The Relationship Between Brand Image And Purchase Intention: Evidence From Award Winning Mutual Funds", The International Journal of Business and Finance Research. Vol 8 (2). p. $27-40$

Zeithaml, V. A (1988) "Consumer Perceptions of Price, Quality, and Value: A MeansEnd Model and Synthesis of Evidence," Journal of Marketing, vol. 52(July), p. 2-22.

\section{Sumber lain :}

http://www.kompas.com.data-angka-kelahiranmenjadi-peluang-pasar.Diakses

September 2015

http://pphp.pertanian.go.id/news/315/peluangdan-tantangan-indonesia-sambut-mea2015 Diakses 17 November 2015 